\title{
PENGARUH KUALITAS PRODUK, HARGA DAN CITRA MEREK TERHADAP KEPUTUSAN PEMBELIAN SMARTPHONE APPLE DI IBOX GANDARIA CITY
}

\author{
Irene Marsella, Lucy Nancy ${ }^{1}$ ) \\ E-mail : lucynancysim@gmail.com, marsellairene97@gmail.com \\ 1)Dosen tetap Program S1 Jurusan Manajemen Fakultas Ekonomi dan Bisnis \\ Universitas Satya Negara Indonesia
}

\begin{abstract}
This study aims to determine the effect of Product Quality, Price, and Brand Image on Apple purchasing decisions at Ibox Gandaria City partially or simultaneously. The data used is primary data collected through distributing questionnaires to 100 respondents who have visited and bought at Ibox Gandaria City. The method used in this study is a quantitative method and the results of the study are based on respondents' answers using the Ordinal scale. The data analysis method used in this research is Multiple Linear Regression Test, $F$ Test, $t$ Test and Coefficient of Determination. The results showed that simultaneously (F test) there was a significant effect between Product Quality (XI), Price (X2), Brand Image (X3) variables on Purchase Decision (Y). Partially (t-test) Product Quality and Brand Image have a significant influence on purchasing decisions. While the price has no significant effect on purchasing decisions.
\end{abstract}

Keywords: Product Quality (X1), Price (X2), Brand Image (X3), Employee performance (Y).

\section{PENDAHULUAN}

Perkembangan teknologi komunikasi telah melalui perubahan yang cukup signifikan dari tahun ke tahunnya. Terbukti dengan munculnya berbagai macam perangkat telekomunikasi dengan teknologi yang begitu canggih. Kemunculan teknologi telekomunikasi ini juga didorong oleh kebutuhan masyarakat untuk menghadapi berbagai madalah yang dihadapi dan diselesaikan dalam waktu cepat dan singkat.

Teknologi komunikasi yang saat ini menjadi trend di msyarakat yaitu adanya smartphone. Keberadaan smartphone kini sudah menjadikan kebutuhan masyarakat luas yang memungkinkan penggunannya untuk tetap terhubung melalui fasilitas smartphone tersebut. Pada saat ini, smartphone tingkat hanya sebagai alat untuk berkomunikasi saja, namun sebagai hal yang mencerminkan ikatan emosional dan budaya yang melambangkan status sosial masyarakat sehingga masyarakat berlomba-lomba ingin mengganti smartphone dengan tipe yang baru.

Dalam masa pandemi Covid-19 ini smartphone sebagai media pendukung proses belajar dan bekerja menjadi sangat dibutuhkan untuk penerapan sistem tersebut karena pemerintah sendiri sudah menerapkan pembatasan sosial. Oleh karna itu persaingan di dalam industri elektronik semakin memanas. Dimana setiap merek memiliki keunggulan dari masing masing produk yang dapat menarik pelanggan untuk keputusan pembelian produk tersebut, Ketatnya persingan industri elektonik pada masa pandemi Covid-19 ini memaksa setiap perusahaan untuk lebih memperhatikan beberapa faktor, seperti produk dengan harga terjangkau, produk dengan kualitas produk terbaik dan citra merek yang banyak dikenal.

Berdasarkan data Gabel, dilansir dari laman (lokodata.id) pada kuartal I-2020 penjualan keseluruhan produk e-lektronik turun 40-50 persen dibanding setahun lalu. Penurunan penjualan semakin tajam memasuki kuartal II-2020, terbukti dengan kinerja penjualan yang hanya mencapai 40 persen dari kondisi normal. Hal tersebut telah menggambarkan terjadinya perubahan perilaku konsumen sehingga menyebabkan penurunan keputusan pembelian. 
Ibox adalah reseller terkemuka Produk Premium Apple di Indonesia yang mengkhususkan diri dalam menawarkan produk-produk Apple dan berbagai macam aksesoris pelengkap, software dan lainnya. Menurut inverstor.id Ibox mengalami penurunan pada kuartal I-2020 dengan menutup sementara gerainya sekitar 20-30\% dari total gerai di Indonesia. Banyaknya perusahaan perusahaan retail elektronik yang terkena dampak penurunan pendapatan. Seperti halnya PT.Erajaya Swasembada.Tbk yang menaungi merek Apple yang disebut dengan Ibox. Namun terjadi suatu fenomena dimana penjualan Ibox dari tahun 2019 ke 2020 mengalami penurunan dibandingkan brand smartphone lainnya. Hal ini dinyatakan pada tabel brand indeks sebagai berikut.

Tabel 1. Top Brand Indeks

\begin{tabular}{|l|r|l|l|l|}
\hline \multicolumn{2}{|c|}{2019} & \multicolumn{2}{c|}{2020} & \multirow{2}{*}{ Presentase } \\
\hline Brand & \multicolumn{1}{|l|}{ TBI } & Brand & TBI & \\
\hline Samsung & $46,10 \%$ & Samsung & $46 \%$ & $-0,1 \%$ \\
\hline Oppo & $15 \%$ & Oppo & $15,10 \%$ & $0,1 \%$ \\
\hline Xiaomi & $11,40 \%$ & Xiaomi & $11,60 \%$ & $0,2 \%$ \\
\hline Iphone & $9,60 \%$ & Iphone & $9,10 \%$ & $-0,5 \%$ \\
\hline Vivo & $7,40 \%$ & Vivo & $7,90 \%$ & $0,5 \%$ \\
\hline
\end{tabular}

Hal tersebut dapat terjadi karna adanya dampak dari pandemi Covid-19, yang menyebabkan perubahan perilaku konsumen yang awalnya konsumtif menjadi perilaku Safe to Money. Dari tabel diatas dapat kita lihat bahwa terjadi fluktuatif tingkat penjualan pada brand Apple Iphone, dengan tingkat penurunan sebesar 0,5\%. Sementara pada Samsung mendapatkan posisi pertama mengalami penurunan tingkat penjualan sebesar $0,1 \%$. Brand Oppo pada posisi kedua mengalami kenaikan penjualan sebesar $0,1 \%$. Xiaomi pada peringkat ketiga meglamai kenaikan tingkat penjualan sebesar $0,2 \%$. Dan Vivo pada peringkat terakhir mengalami kenaikan yang paling tinggi dibanding dengan Brand lainnya dengan tingkat pejualan sebesar $0,5 \%$. Pada pernyataan diatas terlihat fenoma bahwa Brand Apple mengalami penurunan yang paling tinggi dibandingkan degan Brand lainnya. Hal tersebut menandakanstrategi pemasarannya yang dipakai Brand Apple masih belum efektif.

\section{Tabel 2. Data penjualan per-bulan di Ibox Gandaria City}

\begin{tabular}{|l|l|l|l|l|l|l}
$\begin{array}{l}\text { Bulan } \\
\text { Tahun }\end{array}$ & $\begin{array}{l}\text { Pendapatan } \\
\text { Per-bulan (RP) } \\
2019\end{array}$ & Target & $\begin{array}{l}\text { Achieve } \\
(\%)\end{array}$ & $\begin{array}{l}\text { Pendapatan } \\
\text { Per-bulan (RP) } \\
2020\end{array}$ & Target & $\begin{array}{l}\text { Achieve } \\
(\%)\end{array}$ \\
\hline Januari & 6.086 .853 .075 & 7.121 .618 .000 & $83 \%$ & 8.278 .389 .109 & 10.008 .900 .000 & $82 \%$ \\
\hline Februari & 4.197 .664 .800 & 5.414 .988 .000 & $71 \%$ & 10.169 .559 .000 & 7.672 .500 .000 & $132 \%$ \\
\hline Maret & 5.417 .188 .652 & 5.525 .533 .000 & $98 \%$ & 6.597 .023 .800 & 8.691 .100 .000 & $87 \%$ \\
\hline Anril & 4.710 .348 .600 & 5.369 .797 .000 & $86 \%$ & No sale & 5.369 .797 .000 & $0 \%$ \\
\hline Mei & 5.661 .364 .042 & 6.114 .273 .000 & $92 \%$ & 1.418 .680 .900 & 6.114 .273 .000 & $23 \%$ \\
\hline Juni & 5.247 .505 .967 & 5.509 .881 .000 & $95 \%$ & 5.857 .578 .200 & 5.509 .881 .000 & $106 \%$ \\
\hline Juli & 5.498 .760 .425 & 5.608 .736 .000 & $98 \%$ & 5.762 .665 .300 & 5.961 .527 .741 & $94 \%$ \\
\hline Agustus & 6.112 .760 .700 & 6.418 .399 .000 & $105 \%$ & 8.425 .824 .115 & 6.380 .000 .000 & $133 \%$ \\
\hline Sentember & 5.806 .637 .960 & 6.259 .000 .000 & $93 \%$ & 5.248 .008 .300 & 7.346 .000 .000 & $71 \%$ \\
\hline Oktober & 4.823 .010 .436 & 5.179 .900 .000 & $93 \%$ & 7.058 .428 .425 & 5.179 .900 .000 & $136 \%$ \\
\hline November & 4.130 .328 .450 & 4.921 .400 .000 & $83 \%$ & 5.929 .732 .251 & 6.143 .940 .730 & $97 \%$ \\
\hline Desember & 14.162 .915 .092 & 8.033 .300 .000 & $176 \%$ & 16.757 .589 .015 & 14.100 .000 .000 & $119 \%$ \\
\hline Total & 71.855 .338 .199 & 71.476 .825 .000 & $98 \%$ & 81.503 .478 .415 & 88.477 .819 .471 & $90 \%$ \\
\hline & & & & & & \\
\hline
\end{tabular}

Sumber: Laporan Tahunan (2019 dan 2020) 


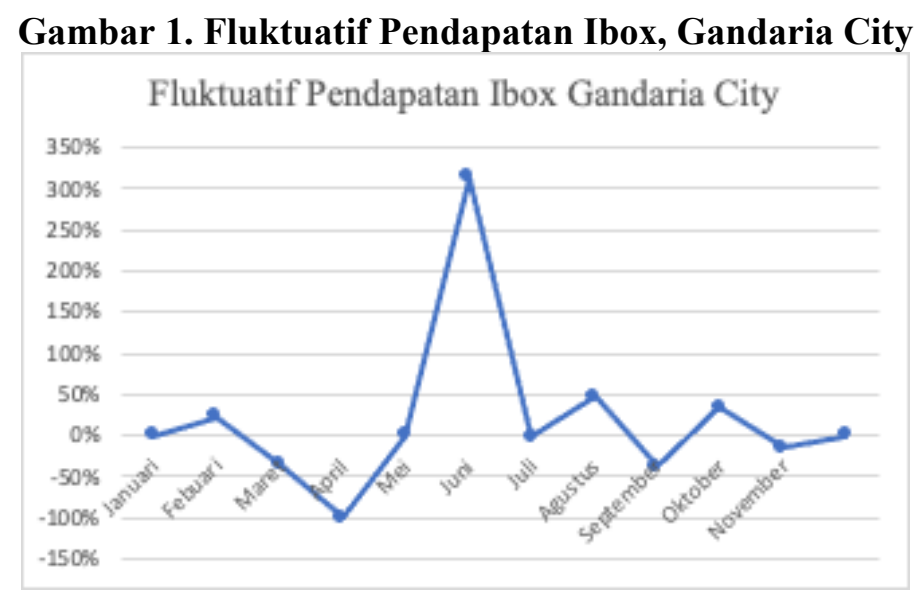

Pada Gambar 1. dapat dijelaskan bahwa telah tejadi fluktuatif pendapatan pada Gandaria City pada tahun 2020. Hal ini dapat kita lihat pada bulan maret dan april terjadi penurunan pendapatan yang sangat ekstrim, walaupun pada bulan mei sampai desember mengalami fluktuatif pendapatan yang mengalami kenaikan dan penurunan, tetap tidak dapat mengembalikan posisi pendapatan seperti pada bulan januari dan februari.

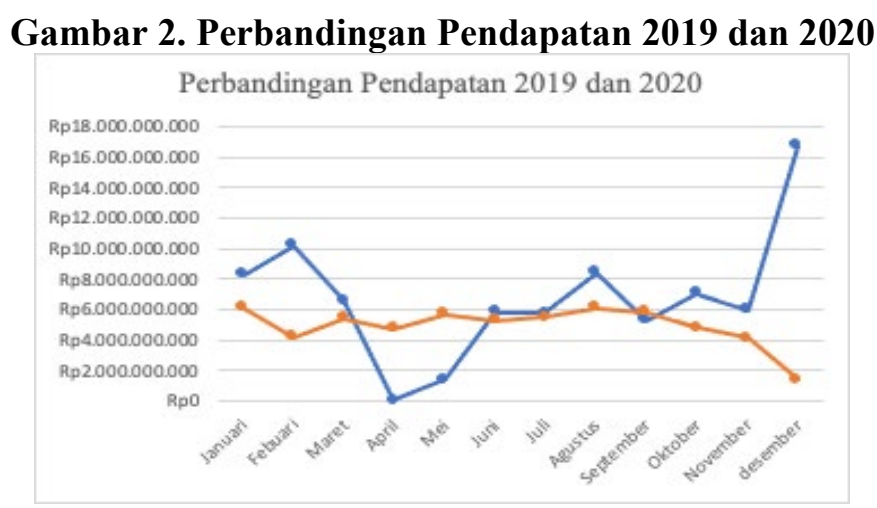

Pada grafik diatas dapat kita lihat bahwa pendapatan pada tahun 2020 mengalami fluktuatif pendapatan yang sangat ekstrim jika dibandingkan tahun 2019 yang bisa dibilang stabil. Terutama pada bulan April 2019 Ibox Gandaria City sempat mencapai titik terendah dengan pendapatan sebesar 0 . Hal ini membuktikan banyaknya faktor faktor yang mempengaruhi keputusan pembelian di Ibox Gandaria City pada tahun 2020. Pihak manajemen Ibox sudah melakukan berbagai macam strategi, tetapi masih belum optimal dalam menghadapi pandemi Covid-19.

Berdasarkan uraian latar belakang diatas, maka penulis tertarik melakukan penelitian dengan judul Pengaruh Kualitas Produk, Harga dan Citra Merek terhadap Keputusan Pembelian Smartphone Apple di Ibox Gandaria City.

\section{TINJAUAN PUSTAKA}

\section{Keputusan Pembelian}

Keputusan pembelian dapat dikategorikan secara garis besar tahap proses pembelian di mulai dari tahap pra-pembelian, konsumsi, dan evaluasi purnabeli. Kesemua proses dilalui manakala konsumen melakukan pembelian berketerlibatan tinggi yaitu pembelian secara psikologis penting bagi konsumen karena menyangkut kebutuhan social, sementara keterlibatan rendah dari proses pencarian informasi dan evaluasi alternative.

Menurut Kotler dan Amstrong (2018:181) Keputusan pembelian konsumen menentukan 
peringkat merek yang disukai dan membentuk niat pembelian.

\section{Kualitas Produk}

Merupakan segala sesuatu yang dapat ditawarkan produsen untuk diperhatikan, diminta, dicari, dibeli, digunakan, atau dikonsumsi pasar sebagai pemenuhan kebutuhan atau keinginan pasar yang bersangkutan. Secara konseptual produk adalah pemahaman subyektif dari produsen atas sesuatu yang bisa ditawarkan, sebagai usaha untuk mencapai tujuan organisasi melalui pemenuhan kebutuhan dan keinginan konsumen, sesuai dengan kompetensi dan kapasitas organisasi serta daya beli pasar.

Kualitas produk menurut Kotler dan Armstrong (2000) adalah sebagai berikut: Segala sesuatu yang dapat ditawarkan ke pasar untuk mendapat perhatian, dibeli, dipergunakan, atau dikonsumsi dan yang dapat memuaskan keinginan atau kebutuhan.

\section{Harga}

Menurut Kotler dan Keller (2016:483) Harga merupakan salah satu unsur bauran pemasaran yang menghasilkan pendapatan, unsur lainnya menghasilkan biaya. Harga juga mengkomunikasikan nilai posisi perusahaan terhadap produk atau mereknya. Produk yang dirancang dengan baik dan dipasarkan masih bisa memberi harga premium dan menuai keuntungan besar

\section{Pengertian Citra Merek}

Citra Merek merupakan suatu hasil pandang atau presepsi konsumen terhadap suatu merek tertentu, yang didasarkan atas pertimbangan dan perbandingan dengan beberapa merek lainnya, pada jenis produk yang sama.

Menurut Kotler (2016:215) Citra Merek adalah seperangkat keyakinan, ide, dan kesan yang dimiliki oleh setiap seseorang terhadap suatu merek. Oleh Karena itu sikap dan tindakan konsumen terhadap suatu merak tersebut.

\section{Kerangka Berfikir Penelitian :}

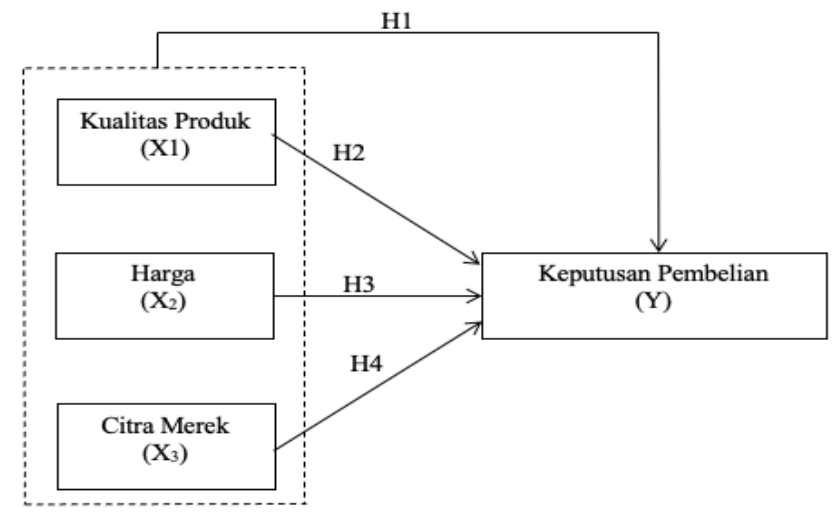

\section{Hipotesis Penelitian}

Merupakan jawaban sementara terhadap rumusan masalah penelitian, dimana rumusan masalah penelitian telah dinyatakan dalam bentuk kalimat pertanyaan. Menurut sugiyono (2018):

H1: Tidak terdapat pengaruh antara variabel Kualitas Produk, Harga dan Citra Merek secara simultan terhadap Keputusan Pembelian apple di Ibox Gandaria City.

H2: Tidak terdapat pengaruh antara variabel Kualitas Produk terhadap Keputusan Pembelian Apple di Ibox Gandaria City.

H3: Tidak terdapat pengaruh antara variabel Harga terhadap Keputusan Pembelian Apple di Ibox Gandaria City.

H4: Tidak terdapat pengaruh antara variabel Citra Merek terhadap Keputusan Pembelian apple di Ibox Gandaria City. 


\section{.METODE PENELITIAN}

Waktu dan Tempat Penelitian

Penelitian dilakukan di Ibox Gandaria City Mall Jalan Sultan Iskandar Muda No.8, RW.6, Kebayoran. Lama Utara, Kec. Kebayoran. Lama, Kota Jakarta Selatan, Daerah Khusus Ibukota Jakarta 12240. Penelitian dilaksanakan pada April 2020 - Juli 2021.

\section{Desain Penelitian}

Desain Penelitian yang digunakan oleh peneliti untuk melakukan penelitian ini adalah Desain Penelitian Asosiatif Kausal. Rumusan masalah penelitian yang bersifat menanyakan hubungan antara dua variabel independent (yang mempengaruhi) dan variabel dependen (dipengaruhi). Menurut Sugiyono (2019:65).

\section{Metode Pengumpulan Data}

Penelitian Kepustakaan (Library Research)

Yaitu dengan cara membaca Buku, Jurnal, Artikel dan Sumber-Sumber Asosiasi yang berhubungan dengan masalah yang diteliti guna memperoleh data teoritis yang relevan dengan pokok persoalan yang dibahas. Hal ini dilakukan untuk mendapatkan tambahan pengetahuan mengenai masalah yang sedang dibahas.

Penelitian Lapangan (Field Research)

Dalam penelitian ini penulis mengumpulkan data yang diperlukan dengan cara melakukan pengamatan langsung pada perusahaan yang bersangkutan, untuk mengumpulkan data yang diperlukan, data tersebut

\section{Populasi dan Sampel}

Adalah wilayah generalisasi yang terdiri atas objek dan subjek yang mempunyai kualitas dan karakteristik. Menurut Sugiyono (2018:126). Populasi target adalah konsumen yang berkunjung pada store Ibox pada Gandaria City.

Sampel adalah bagian dari jumlah dan karakteristik yang dimiliki oleh populasi tersebut. Bila populasi besar, maka peneliti tidak mungkin mempelajari semua yang ada pada populasi. Menurut Sugiyono (2017:81)

a. Teknik pengambilan sampel dalam penelitian ini Nonprobabilty Sampling adalah teknik pengambilan sampel yang tidak memberi peluang/kesempatan yang sama bagi setiap unsur atau anggota populasi untuk dipilih menjadi sampel. Menurut Sugiyono (2018:288).

b. Metode pengambilan sampel dalam penelitian ini Accidental sampling yaitu pengambilan sampel yang dilakukan secara kebetulan, yaitu siapa saja yang dilakukan secara kebetulan bertemu dengan peneliti dapat digunakan sebagai sampel. Menurut Sugiyono (2015:156).

Kriteria responden yang digunakan dalam pemilihan sampel yaitu :

1. Responden berjenis kelamin laki-laki dan perempuan.

2. Responden berusia $20 \mathrm{~s} / \mathrm{d} 40$ tahun ke atas, dengan hal ini bertujuan agar pengisian kuisioner berjalan dengan baik dan maksimal.

3. Responden yang sudah menggunakan produk Apple di Ibox lebih dari satu kali.

Dalam penelitian ini peneliti menggunakan rumus Roscoe dalam menentukan sampel yaitu

$$
\begin{aligned}
& \mathrm{n}=10 \times \mathrm{k} \\
& \mathrm{n}=10 \times 4=40
\end{aligned}
$$

Keterangan :

$\mathrm{n}=$ sampel

$\mathrm{k}=$ varibel penelitian yang digunakan

Dari perhitungan diatas diperoleh hasil minimal 40 sampel, namun peneliti mengambil 100 sampel sebagai responden 


\title{
ANALISIS HASIL DAN PEMBAHASAN
}

\author{
Uji Deskriptif
}

Tabel 3. Descriptive Statistics

\begin{tabular}{|l|l|l|l|l|l|}
\hline & N & $\begin{array}{l}\text { Minimu } \\
\text { m }\end{array}$ & Maximum & Mean & $\begin{array}{l}\text { Std. } \\
\text { Deviation }\end{array}$ \\
\hline Keputusan & 100 & 82 & 165 & 138,53 & 17,532 \\
Pembelian & 100 & 58 & 135 & 110,80 & 15,472 \\
Kualitas Produk & 100 & 45 & 95 & 80,63 & 9,954 \\
Harga & 100 & 59 & 100 & 84,96 & 9,011 \\
Citra Merek & 100 & & & & \\
Valid N (listwise) & & & & \\
\hline
\end{tabular}

Berdasarkan tabel diatas dapat disimpulkan bahwa Keputusan Pembelian memiliki nilai minimum 82 , maximum 165 , mean 138,53 dan standar deviasi 17,532 dalam hal ini jika mean 138,53 dibagi jumlah pernyataan 33 maka didapatkan hasil 4,20, Artinya responden menyatakan penilaian pada pernyataan keputusan pembelian dengan nilai 4,20 yang berarti setuju dengan pernyataan keputusan pembelian dan responden menyatakan penilaian minimum atau tidak setuju dengan kuesioner pernyataan keputusan pembelian dengan nilai 2,48 .

Kualitas Produk memiiki nilai minimum 58, maximum 135, mean 110,80 dan standar deviasi 15,472 dalam hal ini jika mean 110,80 dibagi jumlah pernyataan 27 maka didapatkan hasil 4,10. Artinya responden menyatakan penilaian pada pernyataan Kualitas Produk dengan nilai 4,10 yang berarti setuju dengan pernyataan Kualitas Produk dan responden menyatakan penilaian mininum atau tidak setuju dengan kuesioner pernyataan Produk dengan nilai 2,15 .

Harga memiliki nilai minimum 45, maximum 95, mean 80,63 dan standar deviasi 9,954 dalam hal ini jika mean 80,63 dibagi jumlah pernyataan 19 maka didapatkan hasil 4,24. Artinya responden menyatakan penilaian pada pernyataan Harga dengan nilai 4,24 yang berarti setuju dengan pernyataan Harga dan responden menyatakan penilaian minimun atau tidak setuju dengan kuesioner pernyataan Harga dengan nilai 2,37.

Citra Merek memiliki nilai minimum 59, maximum 100, mean 84.96 dan standar deviasi 9,011 dalam hal ini jika mean 84,96 dibagi jumlah pernyataan 20 maka didapatkan hasil 4,25. Artinya responden menyatakan penilaian pada pernyataan Harga dengan nilai 4,25 yang berarti setuju dengan pernyataan Citra Merek dan responden menyatakan penilaian minumun atau tidak setuju dengan kuesioner pernyataan Harga dengan nilai 2,95.

\section{Uji Intrumen}

Uji validitas

Uji validitas bertujuan untuk mengetahui seberapa valid atau sah tidaknya suatu item dalam pengukuran apa yang ingin diukur (kuesioner). Dalam hal ini penelitian menggunakan metode kolerasi yaitu cara mengkolerasi skor item dengan skor totalnya. Skor total adalah penjumlahan seluruh item pada suatu variabel ( $\mathrm{r}_{\text {hitung }}$ ). Kemudian pengujian signifikan menggunakan $\left(\mathrm{r}_{\text {tabel }}\right)$ pada tingkat signifikan 0,05. Menurut Duwi Priyatno (2014:51).

\section{Uji Reabilitas}

Uji Realibilitas digunakan untuk mengetahui konsistensi alat ukur yang biasanya menggunakan kuesioner. Maksudnya apakah alat ukur tersebut akan mendapatkan pengukuran yang tetap konsisten jika pengukuran diulang kembali. Menurut Duwi Priyatno (2014:64). Uji realibilitas bertujuan untuk menunjukan suatu pengukuran dapat memberikan hasil yang relatif sama. Uji reabilitas merupakan kelanjutan dari uji validitas, 
dimana item yang masuk pengujian adalah item yang valid saja. Untuk menentukan apakah instrumen realibel atau tidak menggunakan Cronbach Alpha 0,6 menurut sekaran (1992) dalam Duwi Priyatno, (2014:64). Reliabilitas kurang dari 0,6 adalah kurang baik, sedangkan 0.7 dapat diterima dan diatas 0,8 adalah baik.

\section{Uji Asumsi Klasik}

Uji Normalitas Residual

Uji normalitas pada model regresi digunakan untuk menguji apakah nilai residual yang dihasilkan dari regresi terdistribusi secara normal atau tidak. Menururt Duwi Priyanto (2014:90). Model regresi yang baik adalah yang memiliki nilai residual yang terdistribusi secara normal. Uji normalitas dengan menggunakan metode grafik yaitu dengan melihat penyebaran data pada sumbu diagonal pada grafik normal $\mathrm{p}$-p of regression standarlized residual dan normalitas kolmogrov smirnov.

Dasar pengambilan keputusan:

Apabila menggunakan metode $\mathrm{p}$ plot, dapat dilihat dari sebaran data-data yang dikatakan normal adalah data yang tersebar disekitar garis diagonal dan apabila nilai signifikan lebih dari 0,05 .

a) Hasil Uji Normalitas Dengan Analisis Grafik P-Plot

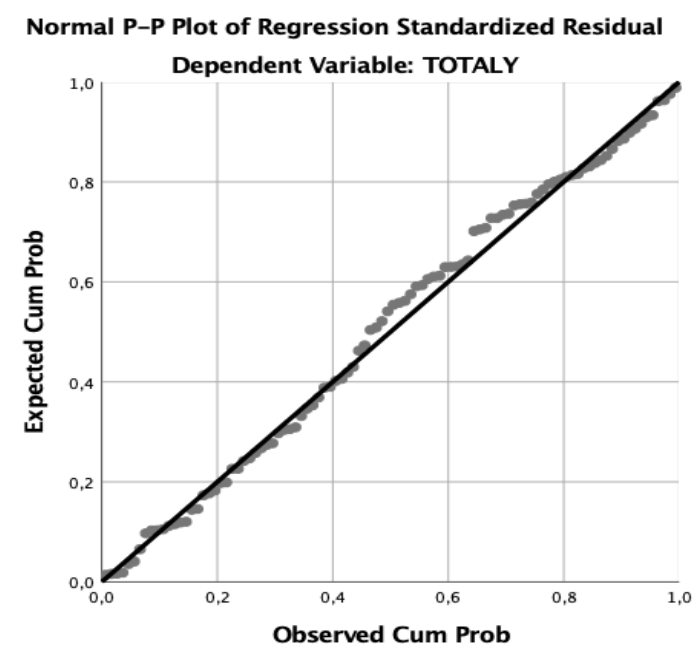

Dari hasil pengolahan data, maka dapat disimpulkan bahwa sebaran data dapat dikatakan normal karena data yang tersebar mengikuti garis diagonal.

b) Hasil Uji Normalitas Dengan Analisis Kolmogorov-Smirnov

Tabel 4. Output Uji Normalitas Kolmogrov Smirnov One-Sample Kolmogorov-Smirnov Test

\begin{tabular}{|c|c|c|c|c|c|}
\hline & & $\begin{array}{l}\text { Keputusan } \\
\text { Pembelian } \\
\end{array}$ & $\begin{array}{l}\text { Kualitas } \\
\text { Produk } \\
\end{array}$ & Harga & $\begin{array}{l}\text { Citra } \\
\text { Merek } \\
\end{array}$ \\
\hline $\mathrm{N}$ & & 100 & 100 & 100 & 100 \\
\hline \multirow[t]{2}{*}{ Normal Parameters ${ }^{\mathrm{a}, \mathrm{b}}$} & \multirow[t]{2}{*}{ Rata-rata } & 138,53 & 110,8 & 80,63 & 84,96 \\
\hline & & 17,352 & 15,472 & 9,954 & 9,011 \\
\hline \multirow[t]{3}{*}{$\begin{array}{ll}\text { Most } & \text { Extreme } \\
\text { Differences } & \end{array}$} & Absolute & 0,064 & 0,082 & 0,079 & 0,082 \\
\hline & Positif & 0,064 & 0,059 & 0,074 & 0,048 \\
\hline & Negatif & $-0,054$ & $-0,082$ & $-0,079$ & $-0,082$ \\
\hline \multicolumn{2}{|l|}{ Test Statistic } & 0,064 & 0,082 & 0,079 & 0,082 \\
\hline
\end{tabular}




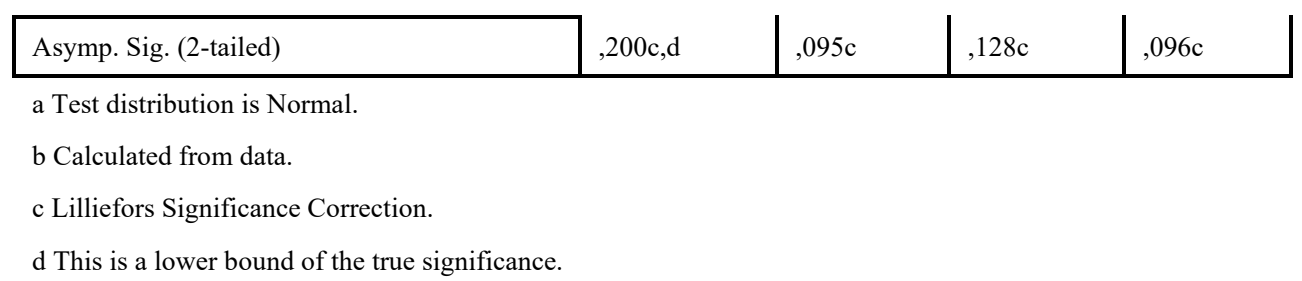

Berdasarkan tabel diatas diperoleh hasil Asymp. Sig. (2-tailed) untuk variabel Keputusan Pembelian $(Y)=0,200>0,05$. Kualitas Produk $\left(X_{1}\right)=0,095>0,05$. Harga $\left(X_{2}\right)$ $=0,128>0,05$. Citra Merek $\left(\mathrm{X}_{3}\right)=0,096>0,05$. Maka dapat diasumsikan bahwa analisis Ha diterima, yang artinya data residual berdistribusi nomal.

\section{Uji Heterokedastisitas}

Heteroskedastisitas adalah varian yang tidak sama pada semua pengamatan didalam metode regresi. Menurut Duwi Priyatno (2014:99). Regresi yang baik seharusnya tidak terjadi heteroskeditisitas. Apabila menggunakan Uji Glejser, dapat dilihat dari sebaran data-data yang dikatakan bebas heteroskedastisitas/ tidak terjadi heteroskeastisitas adalah data yang tersebar/tidak berkumpul disatu titik.

Gambar 3

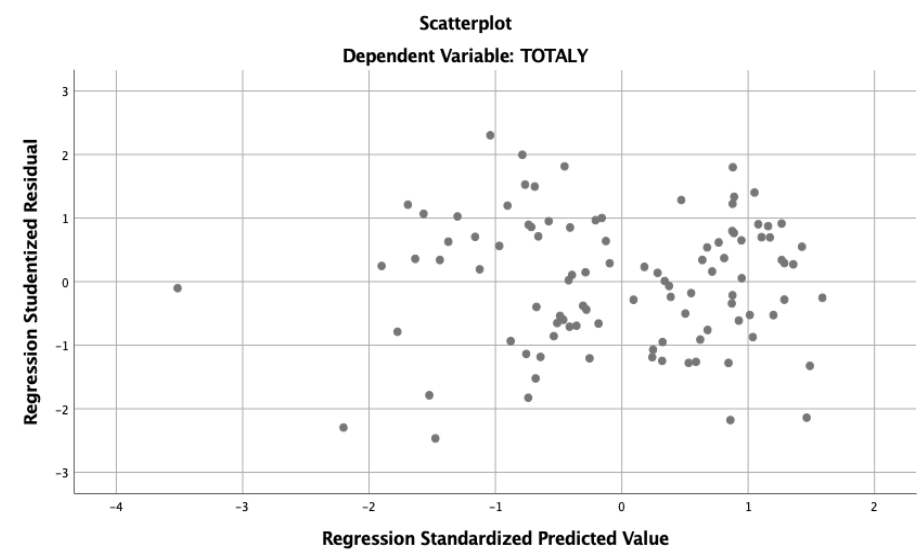

\section{Hasil Uji P-Plot}

Dari output dapat diketahui bahwa titik-titik tidak membentuk pola yang jelas dan titiktitik menyebar diatas dan dibawah angka 0 pada sumbu Y. Jadi, dapat disimpulkan bahwa tidak terjadi heteroskedastisitas dalam model regresi.

\section{Uji Multikolinearitas}

Uji ini bertujuan untuk mengetahui apakah antara variabel bebas yang terdapat dalam model regresi memiliki hubungan linear yang sempurna atau mendekati sempurna. Menurut Duwi Priyatno (2014:99). Model regresi yang sempurna seharusnya tidak terjadi kolerasi sempurna atau mendekati sempurna diantara variabel bebas.

Dasar mengambil keputusan:

Nilai Toleransi $>0.10$ tidak terjadi multikolerasi

Nilai Toleransi $<0.10$ terjadi multikolerasi

Atau dapat juga dengan nilai VIF

Nilai $<10=$ tidak terjadi multikolerasi

Nilai $>10=$ terjadi multikolerasi 
Tabel 5. Output Uji Multikolinearitas, Koefisien ${ }^{a}$

\begin{tabular}{|c|c|c|c|c|c|c|c|c|}
\hline & \multirow{2}{*}{ Model } & \multicolumn{2}{|c|}{$\begin{array}{c}\text { Tidak Standar } \\
\text { Koefisien }\end{array}$} & \multirow{2}{*}{$\begin{array}{c}\begin{array}{c}\text { Standar } \\
\text { Koefisien }\end{array} \\
\text { Beta }\end{array}$} & \multirow{2}{*}{$\mathrm{t}$} & \multirow{2}{*}{ Sig. } & \multicolumn{2}{|c|}{ Statistik Kolinieritas } \\
\hline & & $\mathrm{B}$ & Std Frror & & & & & \\
\hline \multirow{4}{*}{1} & (Konstanta) & 7,658 & 6.853 & & 1.117 & .267 & & \\
\hline & Kualitas Produk & 819 & 068 & .730 & 12,042 & .000 & .457 & 2,188 \\
\hline & Harga &, 102 & .120 & .058 & 849 & .398 & .355 & 2,813 \\
\hline & Citra Merek & 376 & .123 & 195 & 3,068 & .003 & .414 & 2,417 \\
\hline
\end{tabular}

Berdasarkan tabel diatas dapat diketahui bahwa Kualitas Produk (X1) mempunyai nilai Toleransi 0,457, Harga $\left(\mathrm{X}_{2}\right)$ mempunyai nilai Toleransi 0,355, dan Citra Merek $\left(\mathrm{X}_{3}\right)$ mempunyai nilai Toleransi 0,414. Sedangkan Kualitas Produk (X1) mempunyai nilai VIF 2,188, Harga $\left(\mathrm{X}_{2}\right)$ mempunyai nilai VIF 2,813, dan Citra Merek $\left(\mathrm{X}_{3}\right)$ mempunyai nilai VIF 2,417. Maka dapat disimpulkan bahwa tidak terjadi multikolerasi antar variabel adalah lebih besar dari 0,10 dan nilai VIF (Variance Inflation Factory) untuk masing-masing variabel adalah lebih kecil dari 10.

\section{Uji Autokorelasi}

Autokorelasi merupakan kolerasi antara anggota observasi yang disusun menurut waktu dan tempat. Menurut Duwi Priyatno (2014:106). Menurut regresi yang baik seharusnya tidak terjadi autokolerasi. Metode pengujian menggunakan Uji Dubin Watson (DW test).

Dasar pengambilan keputusan

$\mathrm{DU}<\mathrm{DW}<4$ - DU maka $\mathrm{H}_{\mathrm{o}}$ diterima artinya tidak terjadi autokolerasi.

$\mathrm{DW}<\mathrm{DL}$ atau DW $>4-\mathrm{DL}$ maka $\mathrm{H}_{0}$ ditolak, artinya tidak ada kepastian atau kesimpulan yang pasti.

Tabel 6. Output Uji Autokolerasi

\begin{tabular}{|l|l|l|l|l|l|}
\hline Model & R & R Square & $\begin{array}{l}\text { Adjusted } \\
\text { Square }\end{array}$ & $\begin{array}{l}\text { R } \\
\text { Std. Error of the } \\
\text { Estimate }\end{array}$ & Durbin-Watson \\
\hline 1 & $.916^{\mathrm{a}}$ & .839 & .834 & 7.074 & 2.179 \\
\hline
\end{tabular}

a. Predictors: (Constant), Citra Merek, Harga, Kualitas

b. Dependent Variable: Keputusan Pembelian

Berdasarkan table diatas, dapat diketahui bahwa nilai dari Durbin Watson dengan variabel bebas sebanyak 3 variabel adalah 2,179, dapat dipakainya rumus dari table Durbin Watson dengan $\mathrm{k}=3$ yaitu $\mathrm{DU}=1,736$. Metode pengujian menggunakan Uji Dubin Watson (DW test) dengan dasar pengambilan keputusan bahwa $1,736<2,179<2,264$ maka $\mathrm{H}_{\mathrm{o}}$ diterima artinya tidak terjadi autokolerasi.

\section{Uji Korelasi dan Regresi Linier Berganda}

\section{Uji Korelasi}

Menurut Duwi Priyatno (2014:123) Analisis kolerasi sederhana adalah hubungan antara dua variabel. Dalam perhitungan kolerasi akan didapat koefisien kolerasi yang menunjukkan keeratan hubungan antar dua variabel tersebut. nilai koefisien kolerasi bekisar antara 0 sampai 1 atau 0 sampai -1 , nilai semakin mendekati 1 atau -1 , maka hubungan semakin erat. Jika nilai koefisien kolerasi mendekati 0 maka hubungan semakin lemah.

Menurut Sugiyono (2016:184) pedoman untuk menginterpretasikan hasil koefisien kolerasi antara lain sebagai berikut: 
Tabel 7. Interprestasi Koefisien Korelasi

\begin{tabular}{|l|l|}
\hline Indeks Korelasi & Penafsiran \\
\hline $0,00-0,199$ & Sangat Rendah \\
\hline $0,20-0,399$ & Rendah \\
\hline $0,40-0,599$ & Sedang \\
\hline $0,60-0,799$ & Kuat \\
\hline $0,80-1,000$ & Sangat Kuat \\
\hline \multicolumn{2}{|c|}{ Sumber: Sugiyono 2016 } \\
\hline
\end{tabular}

Untuk menganalisa korelasi antara variabel Kualitas Produk, Harga, dan Citra Merek dapat dilihat dari hasil output SPSS sebagai berikut:

Tabel 8. Hasil Uji Korelasi

\begin{tabular}{|ll|l|l|l|l|}
\hline & & $\begin{array}{l}\text { Keputusan } \\
\text { Pembelian }\end{array}$ & $\begin{array}{l}\text { Kualitas } \\
\text { Produk }\end{array}$ & Harga & Citra Merek \\
\hline Keputusan & Pearson Correlation & 1 & $899^{*}$ & $.725^{*}$ & $.717^{* *}$ \\
Pembelian & Sig. (2-tailed) & 100 & .000 & .000 & .000 \\
& $\mathrm{~N}$ & 100 & 100 & 100 \\
\hline Kualitas Produk & Pearson Correlation &, $899^{* *}$ & 1 & .713 & .655 \\
& Sig. (2-tailed) & .000 & & .000 & .000 \\
& $\mathrm{~N}$ & 100 & 100 & 100 & 100 \\
\hline Harga & Pearson Correlation & .725 & 713 & 1 & .745 \\
& Sig. (2-tailed) & .000 & .000 & 100 & 100 \\
& $\mathrm{~N}$ & 100 & 100 & 100 & 1 \\
\hline Citra Merek & Pearson Correlation & $.717^{* *}$ & 655 & .745 & 1 \\
& Sig. (2-tailed) & .000 & 000 & .000 & 100 \\
& $\mathrm{~N}$ & 100 & 100 & 100 & \\
\hline
\end{tabular}

Berdasarkan tabel diatas, angka koefisien korelasi positif, menunjukkan hubungan positif yang merupakan hasil uji korelasi, maka dapat ditarik kesimpulan yaitu:

1. Korelasi Kualitas Produk terhadap Keputusan Pembelian Diketahui bahwa korelasi antara variabel Kualitas Produk terhadap Keputusan Pembelian. $r=0,899$, hal ini menunjukkan bahwa hubungan positif atau searah yang sangat kuat.

2. Korelasi Harga terhadap keputusan pembelian.

Diketahui bahwa korelasi antara variabel Harga terhadap Keputusan Pembelian $r=$ 0,725 , hal ini menunjukkan bahwa hubungan positif atau searah yang kuat.

3. Korelasi Citra Merek terhadap keputusan pembelian.

Diketahui bahwa korelasi antara variabel Citra Merek terhadap Keputusan Pembelian $r=0,717$, hal ini menunjukkan bahwa hubungan positif atau searah yang sangat kuat.

\section{Uji Regresi Linier Berganda}

Regresi linear berganda bermaksud meramalkan bagaimana keadaan naik turunnya variabel dependen, bila terdapat dua atau lebih variabel independen sebgai faktor prediktor dimanipulasi (dinaik turunkan nilainya). Jadi, analisis regresi linier berganda dilakukan antara variabel Kualitas (X1), Harga (X2), Citra Merek (X3) dan Keputusan Pembelian (Y).

Tabel. 9. Output Uji Regresi Linier Berganda

\begin{tabular}{|c|c|c|c|c|c|c|c|c|}
\hline \multirow{2}{*}{\multicolumn{2}{|c|}{ Model }} & \multicolumn{2}{|c|}{ Tidak Standar Koefisien } & \multirow{2}{*}{$\begin{array}{l}\text { Standar } \\
\text { Koefisien } \\
\text { Beta } \\
\end{array}$} & \multirow{2}{*}{$\mathrm{t}$} & \multirow{2}{*}{ Sig. } & \multicolumn{2}{|c|}{ Statistik Kolinieritas } \\
\hline & & $\mathrm{B}$ & Std. Error & & & & Toleransi & VIF \\
\hline \multirow{4}{*}{1} & (Constant) & 7,658 & 6,853 & & 1,117 & .267 & & \\
\hline & Kualitas Produk &, 819 &, 068 & .730 & 12,042 & .000 & .457 & 2,188 \\
\hline & Harga &, 102 & .120 & .058 &, 849 & .398 & .355 & 2,813 \\
\hline & Citra Merek &, 376 & .123 &, 195 & 3,068 & .003 & .414 & 2,417 \\
\hline
\end{tabular}


Persamaan regresi dari Outpot SPSS diatas adalah sebagai berikut :

$\mathrm{Y}=7,658+0,819+0,102+0,376+\mathrm{e}$

Berdasarkan persamaan regresi diatas maka dapat disimpulkan:

1) Nilai konstanta sebesar 7,658 yang berarti jika variabel Kualitas Produk (X1),Harga $\left(\mathrm{X}_{2}\right)$, dan Citra Merek $\left(\mathrm{X}_{3}\right)$ bernilai 0 maka keputusan pembelian $(\mathrm{Y})$ bernilai 7,658.

2) Nilai koefisien regresi variabel Kualitas Produk (X1) sebesar 0,819 bernilai positif mempunyai arti bahwa jika regresi terhadap Kualitas Produk (X1) semakin baik, maka keputusan pembelian meningkat.

3) Nilai koefisien regresi variabel Harga $\left(X_{2}\right)$ sebesar 0,102 bernilai positif mempunyai arti bahwa jika regresi terhadap Harga $\left(\mathrm{X}_{2}\right)$ semakin baik, maka keputusan pembelian meningkat.

4) Nilai koefisien regresi Citra Merek $\left(X_{3}\right)$ sebesar 0,376 bernilai positif mempunyai arti bahwa jika regresi terhadap Citra Merek $\left(\mathrm{X}_{3}\right)$ semakin baik, maka keputusan pembelian meningkat.

5) Nilai standar error untuk meminimalisir kesalahan yang terjadi sehingga nilai e yang didapat sebesar 6,853 .

\section{Uji Hipotesis}

\section{Uji F (Uji Simultan)}

Uji $\mathrm{F}$ menunjukan apakah semua variabel independen mempunyai pengaruh secara bersama-sama terhadap variabel dependen. Dengan tingkat signifikan $(\alpha)=0,05$ adalah dengan membandingkan nilai $\mathrm{F}_{\text {hitung }}$ dengan $\mathrm{F}_{\text {tabel. }}$. Dan dapat disimpulkan dengan rumus seperti berikut:

nilai $F_{\text {hitung }}>F_{\text {tabel }}$ dan Nilai Signifikan $<(\alpha)=0,05$

$$
\text { nilai } \mathrm{F}_{\text {hitung }}>\mathrm{F}_{\text {tabel }} \text { dan Nilai Signifikan }<(\alpha)=
$$

Tabel 10. Output Uji F (Uji Simultan) ANOVA ${ }^{a}$

\begin{tabular}{|ll|l|l|l|l|l|}
\hline Model & & Sum of Squares & df & Mean Square & F & Sig. \\
\hline 1 & Regression & 25002,779 & 3 & 8334,260 & 166,542 & $.000^{\mathrm{b}}$ \\
& Residual & 4804,131 & 96 & 50,043 & & \\
Total & 29806,910 & 99 & & & \\
\hline
\end{tabular}

a. Variabel Dependen: Keputusan Pembelian

b. Predictors: (Konstanta), Citra Merek, Kualitas Produk, Harga

Pada tabel diatas menunjukkan hasil uji $\mathrm{F}$ dengan nilai sebesar 166,542 $>2,699$ dan nilai signifikasi sebesar $0,000<0,05$ maka Ha diterima. Sehingga dapat disimpulkan bahwa Kualitas Produk $\left(\mathrm{X}_{1}\right)$, Harga $\left(\mathrm{X}_{2}\right)$, dan Citra Merek $\left(\mathrm{X}_{3}\right)$ secara simultan berpengaruh terhadap keputusan pembelian (Y).

\section{Uji t ( Uji Parsial )}

Uji t pada dasarnya menunjukan seberapa jauh pengaruh satu variabel independen secara individual dalam menerangkan variabel dependen secara parsial. Dasar pengambilan keputusan digunakan dalam uji t adalah sebagai berikut:

Jika $t_{\text {hitung }}<t_{\text {tabel }}$ maka $\mathrm{H}_{0}$ diterima dan jika $\mathrm{t}_{\text {hitung }}>\mathrm{t}_{\text {tabel }}$ maka $\mathrm{H}_{0}$ ditolak. Berdasarkan signifiansi, jika signifikansi $>0,05$ maka Ha diterima dan jika signifikansi $<0,05 \mathrm{Ha}$ ditolak. Menentukan $t_{\text {hitung }}$ dapat dilihat pada $t_{\text {tabel }}$ signifikan 0,05 dengan derajat kebebasan $\mathrm{df}=\mathrm{n}-\mathrm{k}-1$, atau $\mathrm{df}=100-3-1=96$ maka diperoleh tabel sebesar 
Berdasarkan perhitungan pada tabel dapat diuraikan hasil pengujian hipotesis parsial

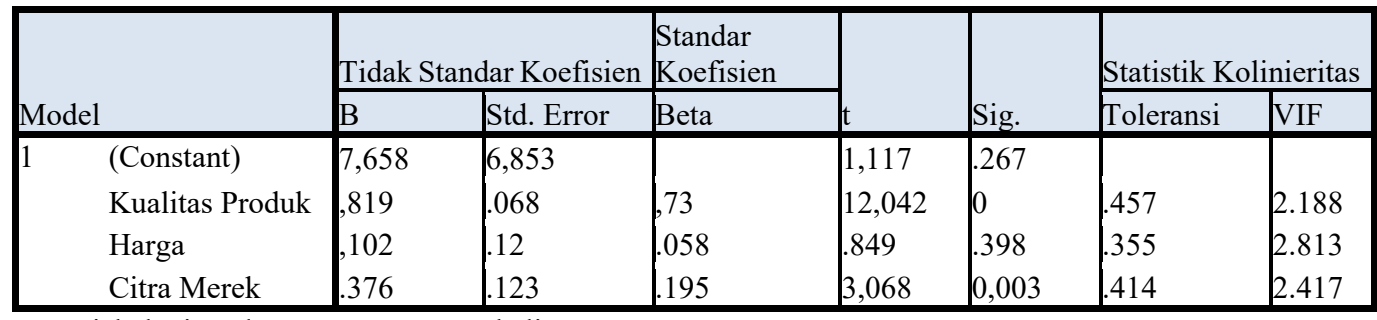

a. Variabel Dipenden: Keputusan Pembelian sebagai berikut:

a. Variabel Kualitas Produk mempunyai nilai $t_{\text {hitung }} 12,042>t_{\text {tabel }} 1,985$ dengan nilai signifikansi $0,000<0,05$ sehingga $\mathrm{H}_{0}$ ditolak Ha diterima, berarti Kualitas Produk terdapat pengaruh signifikan terhadap keputusan pembelian.

b. Variabel Harga mempunyai nilai $t_{\text {hitung }} 0,849<\mathrm{t}_{\text {tabel }} 1,985$ dengan nilai signifikansi 0,403 $>0,05$ sehingga $\mathrm{H}_{0}$ diterima Ha ditolak, berarti Harga tidak berpengaruh terhadap keputusan pembelian.

c. Variabel Citra Merek mempunyai nilai $t_{\text {hitung }}$ 3,068 $>t_{\text {tabel }}$ 1,985 dengan nilai signifikansi $0,003<0,05$ sehingga $\mathrm{H}_{0}$ ditolak $\mathrm{Ha}$ diterima, berarti Citra Merek terdapat pengaruh signifikan terhadap keputusan pembelian.

\section{Uji $\mathbf{R}^{2}$ (Koefisien Determinasi)}

Determinasi $\mathrm{R}^{2}$ mencerminkan kemampuan variabel dependen. Tujuan analisis ini adalah untuk menghitung besarnya pengaruh Kualitas Produk (X1), Harga ( $\left.\mathrm{X}_{2}\right)$, dan Citra Merek $\left(\mathrm{X}_{3}\right)$, terhadap keputusan pembelian. $(\mathrm{Y})$.

Tabel 12. Output Analisis Koefisien Determinasi $\left(\mathbf{R}^{2}\right)$

\begin{tabular}{|c|c|c|c|c|c|}
\hline Model & $\mathrm{R}$ & R Square & Adjusted R Square & $\begin{array}{c}\text { Std. Error of the } \\
\text { Estimate }\end{array}$ & Durbin-Watson \\
\hline 1 &, $916^{\mathrm{a}}$ &, 839 &, 834 & 7,074 & 2.179 \\
\hline
\end{tabular}

a. Predictors: (Constant), Citra Merek, Kualitas Produk, Harga

b. Dependent Variable: Keputusan Pembelian

Dalam penelitian ini Kualitas Produk $\left(\mathrm{X}_{1}\right)$, Harga $\left(\mathrm{X}_{2}\right)$, dan Citra Merek $\left(\mathrm{X}_{3}\right)$ berpengaruh sebesar $83,4 \%$ terhadap keputusan pembelian (Y) dan sisanya sebesar $(100 \%$ $-83,4 \%=16,6 \%$ ) dipengaruhi oleh variabel lain yang tidak dijelaskan dalam penelitian ini.

\section{Pembahasan dan Interpretasi}

\section{Pengaruh Kualitas Produk Terhadap Keputusan Pembelian}

Berdasarkan hasil uji hipotesis Penelitian yang telah dilakukan penulis menunjukkan bahwa variabel Kualitas Produk $\left(\mathrm{X}_{1}\right)$ Konsisten, dan Kualitas Produk berpengaruh signifikan terhadap keputusan pembelian pada Ibox Gandaria City, hal itu diketahui dari nilai $\mathrm{t}_{\text {hitung }} 12,042>\mathrm{t}_{\text {tabel }} 1,985$ dengan nilai signifikansi $0,000<0,05$ sehingga $\mathrm{H}_{0}$ ditolak Ha diterima.

Kualitas Produk adalah sesuatu yang dapat ditawarkan ke pasar untuk diperhatikan, dipakai, dimiliki, atau dikonsumsikan sehingga dapat memuaskan keinginan atau kebutuhan Anang Firmansyah, (2019:186). Kualitas produk Apple yang disuguhkan ke konsumen pun tidak bisa dianggap remeh, mulai dari durabilitas yang tinggi, (Waterprof 5rpm), Screen Guard yang tidak mudah pecah, dan desain yang terbuat dari bahan metal yang membuatnya terlihat lebih elegan. Hal tersebut merupakan keunggulan dari produk Apple yang membuat pelanggan tertarik dan memutuskan untuk melakukan pembelian. Namun karena semakin meningkatnya penyebaran covid-19, pelanggan enggan datang langsung ke Store Ibox untuk membeli produk yang dibutuhkan. Sehingga Ibox Gandaria 
City mengalami penurunan keputusan pembelian secara langsung. Menurut penelitian yang dilakukan oleh Eko Susanto, Jasman (2021) yang menyatakan bahwa Kualitas Produk berpengaruh terhadap keputusan pembelian Smartphone Realme pada kabupaten Ogan Komeing Ilir.

Dari tabulasi data pada variabel kualitas produk yang terdiri dari 3 dimensi yaitu Fungsi Produk, Fitur produk, Keandalan Produk. Menunjukkan bahwa responden menganggap Kualitas Produk di Ibox Gandaria City sudah baik. Hal ini dilihat dari nilai skor rata-rata pada variabel Produk sebesar 4,10. Dilihat dari per-dimensi pada variabel Kualitas Produk skor terendah adalah fitur produk dengan nilai 3,95 yang berarti fitur produk Ibox Gandaria City masih setuju di mata responden. Fitur produk tersebut menurut penilaian responden terkait dengan Konsisten dan Realita sudah bagus. Sedangkan untuk dimensi Fungsi produk memiliki skor 4,18 dimana pada dimensi ini responden Ibox melihat dalam hal manfaat yang dirasakan, karakteristik produk, dan kesesuaian Produk yang baik, maka hal yang dilakukan manajemen Ibox Gandaria City harus mempertahankan Fungsi Produk tersebut. Sebaliknya, perlu ada koreksi atau harus ditingkatkan lagi terhadap Fitur Produk mengingat karena skor nya menurut responden paling rendah diantara dimensi lainnya.

\section{Pengaruh Harga terhadap Keputusan Pembelian}

Berdasarkan hasil uji hipotesis Penelitian yang telah dilakukan peneliti menunjukkan bahwa variabel variabel Harga $\left(\mathrm{X}_{2}\right)$ tidak terdapat pengaruh terhadap keputusan pembelian pada Ibox Gandaria City, hal itu diketahui dari nilai $t_{\text {hitung }} 0,849<\mathrm{t}_{\text {tabel }} 1,985$ dengan nilai signifikansi 0,403 $>0,05$ sehingga $\mathrm{H}_{0}$ diterima Ha diterima.

Faktor yang mempengaruhi keputusan pembelian yaitu harga. Pelanggan akan mempertimbangakan harga dengan baik apakah produk yang di beli sesuai dengan harga yang ditawarkan. Pada pemasarannya, Ibox menawarkan harga sesuai dengan pelanggan di Indonesia dalam golongan kelas menengah ke atas. Adanya kampanye diskon yang sangat menarik perhatian pelanggan terutama pada Apple User tersebut. Pemotongan harga ditunjukkan pada produk-produk sebelumnya yang akan digantikan oleh produk baru. Sering kali juga Ibox Gandaria City bekerja sama dengan pihak Bank untuk memberikan diskon dengan memakai kartu kredit dan memberikan tawarkan menarik lainnya berupa cicilan $0 \%$ dengan minimun pembelian tertentu. Namun krisisnya ekonomi yang disebabkan oleh adanya pandemi, menyebabkan labilnya keputusan manajemen Ibox untuk melakukan penyesuaian harga. Karena dapat mengalami kerugian besar pada perusahaan. hal tersebut juga menjadi pertimbangan bagi pelanggan yang mengalami penurunan pendapatan.

Pernyataan tersebut juga telah dilakukan oleh penelitian yang dilakukan oleh Indra Masrin, Rindi Putra Yanto, (2019), yang menyebutkan bahwa Faktor Harga berpengaruh secara signifikan terhadap Keputusan Pembelian Smartphone Oppo.

Dari tabulasi data pada variabel Harga yang terdiri dari 3 dimensi yaitu Daftar Harga, Diskon dan Metode Pembayaran. Menunjukkan bahwa responden melihat Harga yang diberikan sudah baik. Hal ini dilihat dari nilai skor rata-rata pada variabel Harga sebesar 4,24. Namun dilihat per-dimensi variabel Harga skor terendah adalah Daftar Harga dengan nilai 4,08 yang berarti Daftar Harga di Ibox Gandaria City masih setuju di mata responden. Daftar Harga tersebut menurut penilaian responden terkait dengan Harga bersaing, harga sesuai kualitas, dan harga sesuai manfaat sudah bagus. Sedangkan untuk dimensi Diskon memiliki skor 4,38 dimana pada dimensi ini responden Ibox Gandaria City melihat bahwa diskon musiman, diskon kartu debit atau kredit, dan diskon barang tertentu dianggap bagus, maka hal yang dilakukan manajemen Ibox Gandaria City harus mempertahankan dimensi Diskon tersebut. Sebaliknya, perlu ada koreksi atau peningkatan terhadap Daftar Harga mengingat karena skor nya menurut responden paling rendah diantara dimensi lainnya. 


\section{Pengaruh Citra Merek Terhadap Keputusan Pembelian}

Berdasarkan hasil uji hipotesis Penelitian yang telah dilakukan peneliti menunjukkan bahwa Citra Merek $\left(\mathrm{X}_{3}\right)$ berpengaruh signifikan terhadap keputusan pembelian Ibox Gandaria City, hal itu diketahui dari nilai nilai $t_{\text {hitung }} 3,068>t_{\text {tabel }} 1,985$ dengan nilai signifikansi $0,003<0,05$ sehingga $\mathrm{H}_{0}$ ditolak Ha diterima.

Menurut Kotler (2016:215) Citra Merek adalah seperangkat keyakinan, ide, dan kesan yang dimiliki oleh setiap seseorang terhadap suatu merek. Oleh Karena itu sikap dan tindakan konsumen terhadap suatu merak tersebut. Citra merek Ibox tidak perlu diragukan lagi ,karena merupakan produk Internasional yang sudah tersebar di berbagai negara. Barang mewah sudah melekat di benak konsumen jika mendengar produk Apple. Banyak dari konsumen yang rela menghabiskan pendapatan mereka hanya untuk membeli produk dari perusahaan tersebut, sehingga semua produk tersebut masuk kedalam golongan barang tersier yang diinginkan oleh beberapa konsumen yang haus akan kenaikan status. Pernyataan tersebut telah diteli oleh Kadek Ayuk Riska Oktavenia, (2019), menyatakan bahwa Smarthphone Nokia berpengaruh terhadap keputusan pembelian konsumen di Bali. Dari tabulasi data pada variabel Citra Merek yang terdiri dari 3 dimensi yaitu Identitas Merek, Personalita Merek dan Etika Merek. Menunjukkan bahwa responden melihat Merek di Ibox Gandaria City sudah bagus. Hal ini dilihat dari nilai skor rata-rata pada variabel Citra Merek sebesar 4,26. Namun dilihat per- dimensi variabel Citra Merek skor terendah adalah dimensi Etika Merek sebesar 4,18 yang berarti dimensi Etika Merek Ibox Gandaria City masih setuju di mata responden. Etika Merek tersebut menurut penilaian responden terkait dengan kejujuran dan Realitas sudah bagus. Sedangkan untuk dimensi Identitas Merek memiliki skor 4,40 dimana pada dimensi ini responden Ibox Gandaria City melihat bahwa Nama Merek dan Logo sudah bagus, maka hal yang dilakukan manajemen Ibox Gandaria City harus mempertahankan dalam Identitas Merek tersebut. Sebaliknya, perlu ada koreksi atau harus ditingkatkan lagi terhadap Etika Merek mengingat karena skor nya menurut responden paling rendah diantara dimensi lainnya

\section{Kesimpulan}

Dari hasil analisis yang dilakukan mengenai Kualitas Produk, Harga, dan Citra Merek terhadap keputusan pembelian, terdapat kesimpulan yang dapat ditarik dari penelitian ini, sebagai berikut:

1. Secara simultan terdapat pengaruh Kualitas Produk, Harga, dan Citra Merek pada Ibox Gandaria City terhadap keputusan pembelian dengan nilai nilai $F_{\text {hitung }}$ sebesar 166,542 dan $\mathrm{F}_{\text {tabel }}$ 2,699 dengan nilai $\mathrm{F}_{\text {hitung }}>\mathrm{F}_{\text {tabel }}$ dan nilai sig $<0,05$ maka $\mathrm{H}_{0}$ ditolak dan $\mathrm{Ha}$ diterima.

2. Secara parsial terdapat pengaruh Kualitas Produk pada Ibox Gandaria City terhadap keputusan pembelian dengan nilai $\mathrm{t}_{\text {hitung }} 12,042>\mathrm{t}_{\text {tabel }}$ 1,985 dengan nilai signifikansi $0,000<0,05$ sehingga $\mathrm{H}_{0}$ ditolak Ha diterima.

3. Secara parsial tidak terdapat pengaruh variabel Harga pada Ibox Gandaria City terhadap keputusan pembelian dengan nilai $\mathrm{t}_{\text {hitung }} 0,849<\mathrm{t}_{\text {tabel }} 1,985$ dengan nilai signifikansi $0,403>0,05$ sehingga $\mathrm{H}_{0}$ diterima Ha ditolak.

4. Secara parsial terdapat pengaruh yang signifikan antara variabel Citra Merek Ibox Gandaria City terhadap keputusan pembelian dengan nilai nilai $t_{\text {hitung }} 3,068>t_{\text {tabel }} 1,985$ dengan nilai signifikansi $0,003<0,05$ sehingga $\mathrm{H}_{0}$ ditolak Ha diterima

\section{Saran}

Adapun saran untuk Ibox Gandaria City antara lain:

a. Manajemen Ibox Gandaria City perlu meningkatkan strategi dalam peningkatan Kualitas Produk agar pelanggan tetap melakukan pembelian bahkan secara berkala.

b. Menetapkan harga yang lebih baik,dengan mengevaluasi serta memperhatikan dimensi yang terendah yaitu ada pada daftar harga dengan rata-rata responden setuju. Berdasarkan pada uji yang telah dilakukan oleh peneliti.

c. Meningkatkan strategi dalam peningkatan Citra Merek agar Merek Ibox selalu menjadi pilihan pelanggan dan dapat meningkatkan dan mempertahankan keputusan $p$ 
d. Diharapkan Penelitian ini dapat menjadi sumber referensi bagi pelanggan dalam melakukan keputusan pembelian pada Ibox Gandaria City Mall terutama dalam masa pandemic Covid-19.

e. Diharapkan Penelitian ini dapat menjadi sumber Edukasi bagi pelanggan dalam memahami sistematika penelitian maupun dalam pemasaran retail.

\section{DAFTAR PUSTAKA}

\section{Sumber Buku:}

Agustina, Shinta. 2011. Manajemen Pemasaran Jilid 1. Brawijaya University. Malang: Tim UB Press.

Firmansyah, Anang. 2019. PEMASARAN (Dasar dan Konsep). Muhammadiyah University. Surabaya: Erlangga

Firmansyah, Anang. 2019. Buku Pemasaran Produk dan Konsep. Muhammadiyah University. Surabaya: Erlangga

Kotler, Philip. Gary Armstrong. (2008). Prinsip-prinsip Pemasaran. Jakarta Erlangga.

Kotler, Philip and Kevin Lane Keller, 2011. Manajemen Pemasaran, Edisi 13 Jilid

1 dan 2, Alih Bahasa : Bob Sabran, Erlangga, Jakarta.

Kotler, Philip dan Kevin Lane Keller. 2012. Manajemen Pemasaran Jilid 1 dan 2. Jakarta: Erlangga.

Kotler, Philip dan Amstrong, Gary. 2014. Principle of Marketing, $12^{\text {th }}$ Edition, Jilid 1 Terjemahan Bob Sabran. Jakarta: Erlangga.

Masculle, Bill. 2007. Market Leader Pre-Intermediate Bussines English Teachers

Resource Book. England: Meteu Cromo

Pratiyno, Duwi. 2017. SPSS 22: Pengolahan Data Praktis. Jakarta: Andi

Tjiptono, Fandi. 2014. Pemasaran Jasa (Prinsip, Penerapan, Penelitian). Yogyakarta: Andi

Tjiptono, Fandy dan Anastasia, Diana. 2016. Pemasaran, Esesnsi dan Aplikasi.Yogyakarta: Andi 